\title{
Challenges in Quality Assurance: A Ten-Year Journey
}

\author{
Jenny Mochtar* and Gan Shu San
}

Petra Christian University, Jl. Siwalankerto 121-131, Surabaya 60236, Indonesia.

\begin{abstract}
Academic quality is defined as the equivalent to academic standards related to student learning outcomes, which consist of specific levels of knowledge, skills, and abilities achieved by students participating in a program. The achievement of academic standards is accommodated by implementing both internal and external quality assurance practices. Internal quality assurance refers to policies and practices used by the higher education institutions to monitor and improve the quality of their education, while external quality assurance refers to policies and practices set up by external parties to assure the quality of higher education institutions and programs. Petra Christian University has built and implemented its internal quality assurance since 2009 based on its unique quality culture. After its ten-year journey and the achievements that Petra Christian University has reached in 2019, the Industrial Revolution 4.0 and Society 5.0 are challenges ahead that Petra Christian University has to face.
\end{abstract}

Keywords: Internal quality assurance system, customer's satisfaction, academic quality, quality management

\section{Introduction}

In 2007, the Indonesian government invited several higher education institutions in Indonesia to be institutionally accredited by the National Accreditation Board for Higher Education (BAN-PT / Badan Akreditasi Nasional Perguruan Tinggi). Established in 1994, BAN-PT is the sole accreditation board recognized by the Indonesian government to assess the quality of higher education (HE - Perguruan Tinggi), the state as well as the private universities [1]. Before 2007, BAN-PT's assessment was limited to the study programs in a HE institution for the levels of diploma, undergraduate (Sarjana), graduate (Magister), and postgraduate (Doktor). The year 2007 marked the first year of BAN-PT's attempt to assess the HE institutions. The invitation to join the assessment was offered to HE institutions, which it was deemed to be qualified, and Universitas Kristen Petra (UK Petra) was one of those institutions. The invitation was accepted with mixed feelings as it was quite an honor, but it would mean hard work for the university members to prepare all the necessary documentation. Because the nature of the assessment was an invitation and not a requirement, UK Petra could either accept or refuse to be assessed by BAN-PT. When it was then decided by the Rector to accept the invitation to be accredited, there was no

\footnotetext{
${ }^{*}$ Corresponding author: jennymd@petra.ac.id
} 
turning back. The Rector appointed an Accreditation Team responsible for preparing all the required documentation to be sent to BAN-PT and to prepare the site-visit by the assessors.

Despite the hard work and long hours, UK Petra's first institutional accreditation was a B. The first result of this accreditation was quite a disappointment and a slap on the face. It is because everybody felt that this university was a university well-known for its quality. Therefore, for the university members, it was a turning point to get an A point by critizing university progress itself with an objective view.

Looking back, in 2007, UK Petra did not have an internal quality assurance system (SPMI-Sistem Penjaminan Mutu Internal). The term quality assurance was not popular because by then, it was assumed that quality assurance was a concept applicable only for the business world and not for an education institution. Even though the government policies on quality assurance were mentioned in UU No. 20 Tahun 2003 tentang Sistem Pendidikan Nasional and PP No. 19 Tahun 2005 tentang Standar Nasional Pendidikan, implementation of quality assurance by HE institutions was never monitored or assessed by the government; thus it was overlooked [3]. The Quality Assurance Office (LPM-Lembaga Penjaminan Mutu) in UK Petra was founded in 2007 just before the institutional accreditation was done to fulfill the government's requirement for a quality assurance office. After the B institutional accreditation was received, the office had no well-planned activities because little was known about the benefits of quality assurance and the lack of knowledge on how to establish an internal quality assurance system.

Without an internal quality assurance system, there were several practices done in UK Petra that had become a negative working culture.

(i). It was strongly believed by the academic and administrative staff that UK Petra was known for its quality in education, and every academic and supporting unit had worked very hard for quality. Little that the authors knew that they worked by using our own definition, needs, and goals for quality and forgot to identify who were our customers, and what were the customers' needs.

(ii). Each unit developed its own system of quality and forgot that the business process owned by one unit was a part of the university's business process. Each unit defined their own business process without paying attention to the business process of other units. As a result, the Standard Operating Procedure (SOP) that reflect the business process owned by one unit, was not linked to the other units.

(iii). The bigger problem was identified when each unit also developed its own information systems that cater to their own needs so that it had several versions of data. As an example, the record of the academic staff owns by the Bureau of General Administration and Personnel was different from the record owned by the Bureau of Academic Administration in terms of the total number of all academic staff, their titles, active status, et cetera. The calculation for workloads and overloads that were related to salaries was done manually.

(iv). The other problem was that almost all UK Petra's academic and administrative staff were loyal employees that had worked in UK Petra more than $20 \mathrm{yr}$ or even $30 \mathrm{yr}$. This was an indicator of a positive condition, yet it also created a negative side in

(v). The sense that it was difficult for them to change as they were already in their comfort zone.

(vi). None of the units or employees in UK Petra had their quality objectives that served as a guide to achieving the university's goals. Critically, the university did not work with quality objectives in mind. Key Performance Indicator (KPI) was not an issue because all of us got the same salary and bonuses regardless of the unit's or an employee's performance. 
Based on these five main problems, the authors concluded that the academic and administrative staff worked very hard. Other problems were because of rarely university performance measurement. Quality was defined from own perspective and not from the university's stakeholders. Thus customer satisfaction was never measured. The information system was just islands of data that are independent entities.

\section{Methods}

This article is a critical review and reflection concerning academic quality in higher education, especially private universities. The authors use the educational achievements historically at that Petra Christian University in $10 \mathrm{yr}$ journey. The results of this article are using several documents in UK Petra to find the problem and the solution rated to internalexternal quality assurance system, management quality, and customer satisfaction in terms of further challenges in the Industrial Revolution 4.0 and Society 5.0.

\section{Quality assurance in Universitas Kristen Petra}

Academic quality is defined as the equivalent to academic standards related to student learning outcomes, which consist of specific levels of knowledge, skills, and abilities achieved by students participating in a program [4]. The achievement of academic standards is accommodated by implementing both internal and external quality assurance practices [5]. Internal quality assurance refers to policies and practices used by the higher education institutions to monitor and improve the quality of their education. In comparison, external quality assurance relates to policies and practices set up by external parties to assure the quality of higher education institutions and programs [6].

However, there are many approaches to developing quality assurance policies, as well as the mechanisms of practicing it [7]. It started university journey in quality assurance by studying several practices from the literature and performing benchmarks to several state universities that have implemented internal quality assurance. At the end of 2009, the university policy applied for a government grant to establish an internal quality assurance system and received a three-year grant to build UK Petra's Internal Quality Assurance System (SPMI-Sistem Penjaminan Mutu Internal). For the Indonesian government, issues of quality assurance and quality enhancement have been a significant focus of attention. Despite differences in the size and stage of development of their higher education sectors, many governments have decided that traditional academic controls are inadequate to today's challenges and that more explicit assurances about the quality are needed [8].

Internal quality assurance in higher education was quite a new concept in 2009, and there were no documents or policies whatsoever that served as guidance on how to develop a system on quality assurance in higher education. The grants provided by the government were to accelerate the internal system in higher education, which focused on continuous improvement.

With this grant, UK Petra focused on three areas to develop, which were:

(i). Building an Internal System of Quality Assurance for continuous improvement

(ii). Implementing Internal Quality Audit

(iii).Developing Quality Culture

Using this grant, UK Petra was able to build UK Petra's Internal System of Quality Assurance in $3 \mathrm{yr}$. National experience in higher education development, four directions for reform, which can be extracted further into three points that fit our university's condition i.e. encouraging uniqueness, synergizing the role of government in higher education, and applying the policies that prioritize quality objectives. It also addressed the importance of 
using technology to improve the quality management system. Furthermore, the importance of student opinion in the quality assurance system is considered [9].

\section{Discussions}

\subsection{The role of government in higher education}

Many governments around the world have concluded that traditional academic control is not sufficient anymore, and a more explicit form of quality assurance is needed [8]. In order to enhance the quality assurance system, many countries have developed accreditation systems such as Indonesia's National Accreditation Agency for Higher Education (NAAHE), Malaysia's Malaysian Qualifications Agency (MQA), and the Philippines' Commission on Higher Education (CHED).

Indonesia government pays serious attention to quality improvement in higher education. There are several initiatives starting with regulations on quality assurance system, nurturing and revitalizing higher education institutions towards quality culture. The regulations include the law on higher education (Undang-undang No. 12 Tahun 2021 tentang Pendidikan Tinggi), Ministerial decree on National Standards for Higher Education (Permenristekdikti No. 44 Tahun 2015 tentang Standar Nasional Pendidikan Tinggi, updated to Permenristekdikti No. 50 Tahun 2018), on Accreditation for Programs and Institutions (Permenristekdikti No. 32 Tahun 2016 tentang Akreditasi Program Studi dan Perguruan Tinggi), Higher Education Database (Permenristekditi No. 61 Tahun 2016 tentang Pangkalan Data Pendidikan Tinggi), and Quality Assurance System for Higher Education (Permenristekdikti No. 62 Tahun 2016 tentang Sistem Penjaminan Mutu Pendidikan Tinggi). Our government also performs several nurturing programs such as conducting quality assurance workshops, internal quality audit workshops, and providing facilitators that help institutions to develop their quality assurance systems. There are revitalizing programs such as foster program and strengthening program for Higher Education Service Institute.

The regulation on quality assurance helped our university to speed up the development and implementation of a quality assurance system. Also, it helps top management to convince middle managers and staff to participate in the system and cultivate the quality culture.

\subsection{Encouraging uniqueness}

As a Christian university, our educational philosophy is clearly defined in the university statute (Statuta Universitas Kristen Petra) stated in 2014 and then updated in 2018. UK Petra education is based on Pancasila (the philosophical basis of the Indonesian state). The paradigm in managing education is based on the Christian World View and Christian Education Philosophy. The framework of our education is faith \& learning integration, and the leadership pattern is servant leadership. These are the foundations that differentiate our university from others and become the center of academic quality.

This philosophy is enacted not only by students but also by the university staff. For students, there are policies and practices to ensure it, such as compulsory classes on Religion, Ethics, Philosophy of Religion and Professional Ethics; Ethic Enrichment Program for first year students; trainings for the senior-students held by a designated team and helped by selected faculties and alumni under a discipleship method; Bible study group; Students Camps and retreats; Veritas lecture, Veritas Seminar, Veritas Question and Answer, Veritas Dialog; Daily prayer meeting and Monday Service; Christian Literature 
Corner and Christian Literature Book Store; Students Fellowship Meeting in every department held regularly and coordinated by Department Student Union. University also encourage and equip students with the ability to relate to others with mercy, justice and respect through programs such as spiritual camp/retreat, blood donation, career camp, community service and involvement in helping victims of natural disasters, Student Peace Building Club and its inter-faith activities; trainings for senior students as mentors for freshmen via spiritual encounters, peer counselling, communication skills, etc.

Students are acquired to enrol in at least one Service Learning course held by the Department as graduation requirement. On the other hand, all departments have to prepare and activate (Community) Service Learning courses related to their field. As for the staff, there are policies and practices to support the philosophy such as trainings and workshop on Christian Teaching Method and Enrichment Program, inviting Christian Professors/ lecturers to share their experiences in teaching methods as well as integrating faith into the learning process, annual teaching satisfaction survey which serves as a tool for feedback to improve faculty's teaching. Also, the university conducts Monday services, fellowships in departments and supporting units for administrators and faculty members, annual retreats, and Leaders Annual Meetings. UK Petra also encourages small groups of staff and students to ensure the integration of faith in the learning process, as well as shaping and boosting the growth of lecturers and students according to the University's values.

It also recognizes university corporate uniqueness in employees' loyalty. The turnover is very low, which means our employees maintain a long affiliation with the university. In the beginning, when the size of our university was very small, most of the employees prioritized quality, as a manifestation of serving God and giving our best for His Glory. Therefore, the level of trust between top management and staff was very high, which unfortunately led to a quite lax system and lack of policy reinforcement.

The working atmosphere was comfortable, friendly, and pleasant — which in Indonesia it is called 'kekeluargaan', literally means "behaving like a family" or kinship - thus a low employee turnover. However, as the institution grows, the spirit of serving and giving our best, no longer shared by all employees. Some employees are interested in joining our university for the opportunities and facilities, not for the idealism in education. Moreover, accumulating long years in the university have also brought about several instances of disgruntled employees who ended up as bitter people who always complain and criticize the policies as well as the facilities. Therefore, the need for internal quality assurance becomes very significant to make sure all the personnel are working to achieve the academic standards set up by the university based on its unique qualities.

Another consideration that stems from long-term employees is the tendency to stay in a comfort zone and become reluctant to change. Staff members tend to perform business as usual regardless of the fierce changes in this disruptive era. The world has changed so fast, followed by the addition of astounding new business models as well as new education paradigms and practices. Therefore, university members need to make continuous improvements in the university through an internal quality assurance system [7].

\subsection{Policies for quality objectives}

Internal policies that support quality assurance system are made based on continuous improvement framework using Plan-Do-Check-Action (PDCA) cycle or using the term in the ministerial decree, i.e., Plan-Do-Evaluate-Correct-Improve (PPEPP--Penetapan Pelaksanaan Evaluasi Pengendalian Peningkatan)

There are three stages of policies development to support quality assurance. The first stage was focused on academic quality assurance where UK Petra developed academic policy and academic standard in the university level, accompanied by academic manuals for study programs, faculties, and university. Also, recognizing the need for key performance 
indicators to make sure, that it is achieving the quality standards set by the university. Therefore, the University decided to use the strategic plan as quality standards. The internal audit was performed, started in 2010, which was the "check" step in PDCA cycle. It was followed by the determination of correction and corrective actions based on the audit findings. Following the audit, the "action" step was done by increasing quality standards or improving the system. The second stage was involving the supporting unit in quality management system based on ISO 9001:2015. The policy was made because of identifying the need for external audit as a level for institutional change [10]. All the academic programs have gone through an external evaluation in the form of accreditation. It turned out to be an excellent decision since the quality system is developed in all areas within the university. The third stage was triggered by the ministerial decree of national standards. Under this regulation, an internal quality assurance system policy was determined that consists of three areas, namely education standards, research standards, and community services standards. This policy covers both academic and supporting units, so the integration of all processes within the university can be recognized by interactions of standards.

\subsection{Technology-based quality assurance system}

The role of enterprise-wide, technology-based continuous quality management system in the quality assurance program at a University in the United States [11]. The system supports the university in developing and utilizing data that is developed to improve the quality of its program and services. UK Petra also has similar experience in using technology-based quality assurance system called SIMutu (Sistem Informasi Mutu / Management Information System for Quality). It was developed in 2012 and is continuously extended based on the need for improving the services, automating the routine tasks, and accommodating changes in policies as well as the management system.

SIMutu covers three functions namely documentation, internal evaluation, and accreditation. The documentation of quality assurance system provided for academic units (programs and faculties) as well as supporting units. SIMutu provides the space for storing all quality documents but the document control remains in the academic unit itself. In addition, SIMutu also provides the target and achievement of key performance indicators, internal audit findings and corrections, accreditation related data, and satisfaction survey results. The driver is accreditation process that requires academic units to show quality assurance documents such as standards and manuals. Another driver is using data to improve the study program's quality and services [11]. However, since academic units hold autonomy in academic activities, the task of documenting becomes a burden.

As for the supporting unit, the drivers of performing documentation are the external audit based on ISO 9001 and the demands from academic units. The document controller is centralized under the Quality Assurance Institute, and this ensures the availability and reliability of quality assurance documents for supporting units. The second function is internal evaluation where SIMutu provides the module for internal audit data that records all the process from preparing the audit, conducting desk evaluation, creating audit findings, documenting the correction and corrective action, and finally writing audit reports. Summary and recommendation are included in audit reports, which is further used by top management to evaluate and make improvements. The third function is supporting the accreditation of programs. SIMutu provides data needed for the Self Evaluation Reports (SER) and Study Program Performance Reports (SPPR). However, since not all units are yet integrated into the university's Management Information System, several data cannot yet be provided. It is an ongoing process to integrate all the data in one system. 


\subsection{Students' engagement in quality assurance system}

As students are the primary users of the services provided by a higher education institution, it is important to know students' opinions about their experiences in the educational process [12]. There are two main areas of students' satisfactions that are measured, i.e. academic qualities and university supports in facilities and infrastructures [11]. University members collect students' opinion on the learning process from all academic departments, specifically the teacher's performance and the learning-teaching facilities. It is a continuous efforts conducted every semester and compulsory for all students to participate. As for the university supports in facilities and infrastructures, students' opinions on all the services such as library, career center, student activity, administration offices, and IT facilities, and many more, are collected annually. The analysis of the collected data is reported to the Rector and becomes one of the considerations in the quality improvement initiatives.

\subsection{UK Petra Reflection}

Finally, being an award-winning campus, the certification from ISO 9001, the five star accreditation from Global Accreditation Association (GAA), and the awards received as one of the best Foster Universities to nurture ten universities in Indonesia in a Foster Program organized by the Ministry of Research, Technology, and Higher Education (MoRTHE), are only some of the recognations received as the result of the continuous effort to improve the internal quality assurance. After the ten-year journey, new challenges ahead are from the Industrial Revolution 4.0 and Society 5.0 waiting not just around the corner but confronting us from all directions.

To face these challenges, UK Petra has equipped itself with a new curriculum, the OBELEAP (Outcome Based Education-Leader Enhancement Program) curriculum as a way to 'leap' forward in this fast-changing era. Thus to be able to leap forward, initiatives such as innovative lectures and teaching methodologies to foster the millenial generation, new directions in research and innovations, international standards in the university service, facilities and infrastructures, are already ready to be implemented. In another ten years to come, UK Petra will become the main reference for other universities in implementing quality assurance. Therefore, it will be a lesson for other universities to face the future Indonesia education challenges.

\section{Conclusions}

In conclusion, as a critical review and reflection of a $10 \mathrm{yr}$ journey of UK Petra in building and implementing a quality assurance system, it has indeed brought satisfactory results. Several great achievements have been obtained by improving the internal quality assurance to the international level. However, after UK Petra at present as an institution with "A" accreditation, it still criticizes self-improvement as a leading university regionally and internationally. Furthermore, from this journey, other private universities can learn several important things related to the internal-external management quality for increasing the academic assurance system. 


\section{References}

1. J. Gunawan, Sosialisasi Permenristekdikti No. 62 Tahun 2016 Tentang SPM Dikti [Socialization of Permenristekdikti No. 62 of 2016 concerning SPM Dikti], Jakarta: Ristekdikti (2016). http://www.kopertis12.or.id/wpcontent/uploads/2016/11/Sosialisasi-Permenristekdikti-No.-62-Tahun-2016-2.pdf

2. D. Hardjito, UK Petra raih akreditasi institusi A dan Anugerah Kampus Unggulan [Petra Petra won accreditation for Institution A and Awarded Excellence Campus], [Online] from http://dwipekan.petra.ac.id/2018/12/04/uk-petra-raih-akreditasiinstitusi-a-dan-anugerah-kampus-unggulan/ (2018). [in Bahasa Indonesia].

3. M. Soekarnoputri, Undang-undang Republik Indonesia nomor 20 tahun 2003 tentang sistem pendidikan nasional. [Law of the Republic of Indonesia number 20 of 2003 concerning the national education system]. Jakarta: Sekretaris Negara Republik Indonesia, (2003). [in Bahasa Indonesia]. https://kelembagaan.ristekdikti.go.id/wpcontent/uploads/2016/08/UU_no_20_th_2003.pdf

4. J. Brennan, T. Shah, Higher education, 40,3:331-349(2000). https://link.springer.com/article/10.1023/A:1004159425182

5. D.R. Sadler, Quality in Higher Education, 23,2:81-99(2017). https://doi.org/10.1080/13538322.2017.1356614

6. O.Y. Krasovska, International Letters of Social and Humanistic Sciences, 66,6166(2016). https://doi.org/10.18052/www.scipress.com/ILSHS.66.61

7. M. Seyfried, P. Pohlenz, European Journal of Higher Education, 8,3:258-271(2018), https://doi.org/10.1080/21568235.2018.1474777

8. M. Beerkens, European Journal of Higher Education, 8,3:272-287(2018). https://doi.org/10.1080/21568235.2018.1475248

9. M. Pourrajab, R. Basri, S.M. Daud, S.B. Asimiran, International Journal of Management in Education, 9,2:200(2015). https://doi.org/10.1504/ijmie.2015.068762

10. A. Al-Maskari, Journal of Management 43,2:29-39(2014), https://www.researchgate.net/publication/327237486_Does_External_Quality_Audit_ make_a_difference/references

11. J.F. Welsh, S. Dey, Quality Assurance in Education, 10,1:17-25(2002). https://doi.org/10.1108/09684880210416076

12. A. Elcigil, H.Y. Sari, Journal of Nursing Education, 47,3:118-23(2008). https://doi.org/10.3928/01484834-20080301-07 